\title{
КОНЦЕПТОТВІРНА ФУНКЦІЯ ЕПІТЕТА У ПОЕЗІЇ ДЖОНА КІТСА: КОРПУСНОБАЗОВАНИЙ ПІДХІД ДО АНАЛІЗУ
}

\begin{abstract}
Анотація. У статті розкрито концептотвірну функцію епітету в поетичній системі Джона Кітса, особливості семантико-когнітивних аспектів епітетів як елементів поетичного дискурсу автора. Дослідження проведено на основі корпуснобазованого підходу та застосування програми конкордансу і програми семантичного аналізу тексту Tropes. На основі частотності іменників та прикметників виявлено домінантні образні моделі епітетизащії в поетичному дискурсі Джона Кітса. Встановлено найчастотніші прикметники та іменники, які виконують стилетвірну та концептотвірну функції та відображають ідостилістичні предеренції поета. Визначено концептуальні домени, які художньо означуються за допомогою епітетів у поезії Кітса.
\end{abstract}

Ключові слова: Джон Кітс, ідіостиль, художній/поетичний концепт, епітет, троп, корпусний підхід аналізу.

Romanyshyn Nataliia, Blashchak Lidia Lviv Polytechnic National University

\section{CONCEPT CREATIVE FUNCTION OF EPITHET IN JOHN KEATS'S POETRY: A CORPUS BASED APPROACH TO THE ANALYSIS}

Summary. The article reveals the conceptual function of the epithet in the poetic system of John Keats, the features of semantic and cognitive aspects of epithets as elements of author's poetic discourse. The study was conducted on the basis of a corpus-based approach and the application of the concordance program and the program of semantic analysis of the text Tropes. Based on the frequency of nouns and adjectives, the dominant figurative models in the poetic discourse of John Keats have been revealed. The most frequent adjectives and nouns that perform stylistic and concept-forming functions and reflect the poet's idystylistic preferences have been established. Conceptual domains that are artistically actualized by the epithets in Keats' poetry are identified. The main way of explicit verbalization of conceptual information is considered to be the keywords, their compatibility and the thematic vocabulary. To optimize the process of keyword selection, the method of constructing concordances of the whole array of author's texts was used. In the work based on the frequency analysis the cognitive and conceptual function of the epithet in the poetry of John Keats was defined. The quantitative analysis of the lexical content of poetic contexts of John Keats was applied to define the author's conceptual system. With the help of the above-mentioned programs the contexts of micro concepts that undergo epithelization were established. Man - man (physical, emotional, behavioral, social); Man is an animal; Man - the physical world (parameters: light, color, temperature); Man - art (music); Man - man (emotional, behavioral, social); Man - the physical world (parameters: matter) are the most frequent figurative models on the basis of which poetic epithets are created. The epithet occupies an important place in the poetics of John Keats. The poet assimilates traditional figurative forms, associated, fixed epithets, endowing them with new meanings within the specific poetic contexts.

Keywords: John Keats, idiosyncrasy, artistic / poetic concept, epithet, trope, corpus approach to analysis.

Постановка проблеми. Дослідження, що виконуються у межах когнітивно-антропоцентричної парадигми сучасної лінгвістики, прагнуть розкрити зв'язок мови та людської когніції, пізнання, креативності, осягнути сутність процесів мовного моделювання дійсності у дискурсі, зокрема художньому / поетичному. Особливої актуальності набуває необхідність поглибленого вивчення мови художнього дискурсу окремого автора або авторів шляхом дослідження їхніх ідіостилів та системи виражально-зображальних засобів. Перед аналітичною діяльністю науковця постає вимога досягнення максимальної об'єктивності результатів, що можуть бути отримані шляхом формалізації опису мовних явищ завдяки можливостями автоматизованої обробки тексту, інструментам корпусної лінгвістики та ідеографрічної лексикографії.

Лінгвістика художнього тексту активно застосовуе формальні методи опису та опращювання мовного матеріалу, алгоритми та методи корпусних досліджень, семантичного опрацювання природної мови за допомогою спеціальних комп'ютерних програм. Сама природа художньої мови суперечлива. 3 одного боку, зміст тексту не може бути виведений із суми значень слів, адже на семантику тексту впливають різноманітні фрактори. 3 іншого боку, частотність мовних елементів тексту, яка є одним із засобів формалізації цього складного та неоднозначного лінгво-когнітивного та лінгво-семіотичного об'екта, дозволяє дослідникам досягти системного опису як сенсу конкретного твору, так і специфріки цілих індивидуальноавторских художніх систем. Розвитку формальної поетики сприяють можливості швидкої обробки великих обсягів даних та створення корпусів, які спроможні проявити смислову структуру тексту, а також концептуальні та стилістичні особливості авторського ідіостилю та його відмінності від інших художніх систем. Дослідження такого плану зумовлені зростаючими вимогами до об'єктивації вивчення тексту та пошуку формалізованих шляхів виявлення індивідуально-авторських ознак літературних творів.

У фрокусі цього дослідження перебуває епітет як один із основних зображально-виражальних 
засобів поетичного мовлення та елемент лінгвоогнітивного плану, який бере участь у створення концептуального простору поетичного твору та формуванні його когнітивно-семантичних та лінгво-поетичних особливостей. Матеріалом дослідження обрано поезію представника молодшої генеращії англійського Романтизму - Джона Кітса.

Аналіз останніх досліджень і публікацій та виділення не вирішених раніше частин загальної проблеми. Епітет неодноразово ставав предметом лінгвістичного вивчення. До аналізу особливостей семантики епітетів, їхнього мовного вираження та фрункціонування в художньому тексті зверталися Ф.І. Буслаєв, О.М. Веселовський, О.О. Потебня, С.Я. Срмоленко, С.П. Бибик, Л.О. Пустовіт, Н.М. Сологуб, В.В. Красавіна. Різнобічне вивчення епітетів перебуває, однак, на периферії досліджень 3 лінгвопоетики та таких сучасних напрямків лінгвістики, як когнітивна поетика та когнітивна стилістика, де основним об'єктом дослідження $є$ інші засоби образності, зокрема метафори, метонімії та порівняння (праці В. Москвіна, Т. Онопрієнка; Б. Томашевського, С.Я. Срмоленко, С.П. Бибик та Л.О. Пустовіт) [1; 2; 4; 5].

Незважаючи на здобутки української та зарубіжної лінгвістики у дослідженні естетики та поетичної системи Романтизму ідіостиль Джона Кітса не отримав достатньої уваги науковців. В українській лінгвістиці окремі аспекти ціеі проблематики висвітлені у працях Романишин H.I. [3, с. 426-466].

Метою цієї статті є розкрити концептотвірну функщію епітету в поетичній системі Джона Кітса. Об'єктом аналізу обрано систему поетичних епітетів у творах цього автора. Предметом аналізу - $є$ особливості семантико-когнітивних аспектів епітетів як елементів поетичного дискурсу Джона Кітса. Основною дослідницькою платформою є здійснення лінгвопоетичного дослідження на основі корпуснобазованого підходу та застосування програми конкордансу і програми семантичного аналізу тексту Tropes.

Виклад основного матеріалу. У творенні естетичної вартості художнього тексту беруть участь усі рівні мови - від фронетичного до синтаксичного, але основна роль належить образній системі твору, вербалізованій різноманітними тропами, серед яких особливе місце належить епітету. Зі сучасних наукових позищій тропи осмислюють як лінгвоментальні категорії, у яких нерозривно пов'язані об'єктивно-пізнавальні та суб'ективно-творчі аспекти. Художній концепт, як і художній образ, розглядають як фррагмент ментальних структур авторської свідомості. Як наслідок, способом осягнення естетичного феномену образності стає поетапний аналіз твору від мовного субстрату до концепту, у якому зримо представлений відповідний предмет. Концепт «заданий» в художньому творі, а його реконструкція можлива за слідами його репрезентації: ключовими словами, синонімічними рядами, семантико-асоціативними рядами імені концепту та іншими групуваннями лексики, зокрема й під час аналізу тропів як результату перетворення мовного матеріалу. Вербальні образи, поряд із так званою «безобразною лексикою», семантичними зрушеннями та конотативними нашаруваннями є засобом експлікації, розгортання художнього концепту. Дослідницький алгоритм, який відображає динамічний характер формування та фрункціонування концептуальної системи художнього тексту в площині їі лінгвопоетичного вияву, передбачає розвиток вектора аналітичних процедур від художніх ресурсів мови тексту до концепту, опису концептосорери твору, визначення місця художнього концепту у світогляді автора.

Основним способом експліцитної вербалізації концептуальної індрормації вважають ключові слова, їхню сполучуваність, тематичну лексику. Для оптимізащії процесу виділення ключових слів високопродуктивною $є$ методика побудови конкордансів як окремих творів, так і всього масиву авторських текстів. Укладені конкорданси для відповідного корпусу текстів дозволяють виділяти та групувати концептуально навантажену лексику відповідно до тематичного «зрізу» контексту, виокремлювати необхідні фррагменти текстів для подальшого аналізу дистрибущії, сполучуваності та семантичного наповнення лексичних вербалізаторів концептів у межах мікрота макроконтекстів.

Концептуальна бункиія епітету в поетичнолу дискурсі Дюсона Кітса (на основі частотності субстантивних колпонентів). Для визначення значення та фрункції епітета у вербалізації стрижневих концептів поетики Джона Кітса у дослідженні було проведено двоетапний аналіз поетичних текстів. На першому етапі будуємо концептуальний профріль поезії автора. Для џьго використовуємо програму семантичного аналізу тексту TROPES. За даними програми TROPES було встановлено, що найбільш репрезентативними концептуальними сорерами поетики Джона Кітса є: Body, feelings, plants, time, animal, space/environment, abstract characteristics, mythology, water, death, life, woman, sleep, language/communication, appearance, cognition, nature/land, що представлені мікроконцептами, номінації яких у поетичних контекстах перевищують 100 токенів (лексичних одиниць). Частотний розподіл елементів концептуального простору поезії Кітса представлено на діаграмі рис. 1.

Таким чином, концептуальний простір поетики Кітса налічуе 17 найчастотніших концептуальних полів.

За допомогою програми встановлюемо специфіку лексичного наповнення кожного з виділених концептуальних полів та його варіативність. Для цього було здійснено частотний аналіз вербалізаторів мікроконцептів, що входять до кожного з виділених полів:

Body: eye, head, hand, heart, hair, face, ear, forehead, bosom, breast. Feelings: joy, love, pleasure, sorrow, delight, wonder, pity, hope. Plants: flower, tree, evy, bush, laurel. Time: day, night, morning, evening, time, end, hour. Animal: swan, skylark, nightingale. Space/environment: sun, planet, Mercury, moon, star, Jupiter, Venus Saturn, heaven, space, sky, cloud, wind, lightning, rain. Abstract characteristics: silence, richness, harmony, strength, tone, echo, voice, sweetness, bitterness, reflection, vigour. Mythology: Heaven, Hell. Water: ocean, sea, river, lake. Death: death, 


\section{REFERENCE FIELDS OF NOUNS}

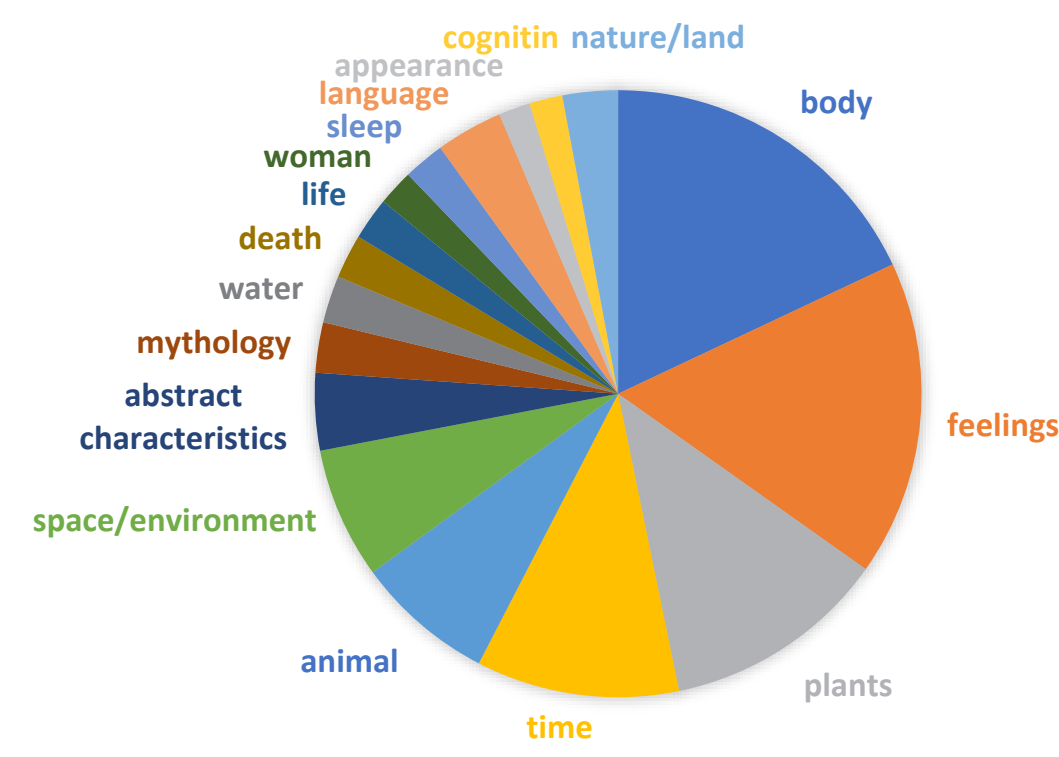

Рис. 1. Частотний розподіл елементів концептуального простору поезії Кітса

Джерело: розроблено авторали

tomb. Life: fate, destiny. Music: song, tune, lullaby, trumpet, harp, melodies. Woman: woman, lady, maid, girl, damsel. Sleep: sleep, dream, slumber, dosing. Language/communication: accent, word, speaking, book, poet, tale, story, gossip, greeting, letter. Appearance: beauty, charm, loveliness. Cognition: thought, mind, knowledge, memory. Nature/land: mountain, valley, forest, dymand, crystal, marbel, sand, water, gold, silver, steel, iron, garden, harvest, atom, desert.

У тій чи іншій мірі виділені іменники-номінації художніх мікроконцептів зазнають процесів художнього перетворення, переносного вживання та художнього означення (епітетизації). Тому другим етапом дослідження є аналіз специфіки процесів художнього означування. Цей етап аналізу був проведений за допомогою програми корпусного аналізу Ant.conc. Було встановлено співвідношення між частотою вживання іменника та частотністю контекстів його епітетизації. Було виявлено, що різні іменники мають різний ступінь епітетизації, вживаючись досить часто (ми аналізували контексти, що мають частоту більше 50), можуть не зазнавати процесів художнього означення. Художні мікроконцепти, що мають низький (менше 10 контекстів епітетизації) або нульовий ступінь епітетизації: ear, pity, skylark, nightingale, planet, Mercury, Jupiter, Venus Saturn,, bitterness, Heaven, Hell, death, accent, letter, gossip, knowledge, memory, atom, desert. Однак, деякі з виділених мікроконцептів зазнають унікальної епітетизації, наприклад:

A gnawing - silent - deadly, quiet death; A bitter death - a suffocating death; O kindly muse! let not my weak tongue faulter; How vain for me the niggard Muse to tease; But might I now each passing moment give To the coy Muse some has been upstirr'd; From out its crystal dwelling in a lake, By a swan's ebon bill There saw the swan his neck of arched snow.
За допомогою програми було встановлено контексти мікроконцептів, що зазнають найвищої епітетизації. Це іменники еye, head, hand, heart, voice, spirit, hour, day (див. таблицю 1).

Таблиця 1

Співвідношення між частотою художніх мікроконцептів та їх ступенем епітетизації

\begin{tabular}{|c|c|c|c|}
\hline $\begin{array}{c}\text { Мікро- } \\
\text { концепт }\end{array}$ & $\begin{array}{c}\text { Частота } \\
\text { вживання }\end{array}$ & $\begin{array}{c}\text { Частота } \\
\text { контекстів } \\
\text { епітетизації }\end{array}$ & Відсоток \\
\hline eye & 215 & 188 & $87 \%$ \\
\hline hand & 96 & 81 & $84 \%$ \\
\hline heart & 98 & 83 & $85 \%$ \\
\hline voice & 67 & 62 & $92 \%$ \\
\hline spirit & 89 & 80 & $90 \%$ \\
\hline hour & 61 & 53 & $86 \%$ \\
\hline day & 121 & 65 & $53 \%$ \\
\hline
\end{tabular}

Джерело: розроблено авторами

Було також встановлено ступінь унікальності епітетів на основі виділених мікроконцептів. 3 поміж 400 контекстів епітетів на основі виділених мікроконтекстів відсоток унікальних метафоричних епітетів становить - $24 \%$. Наприклад: The downcast eye, repentant of the pain; Their lips touch'd not, but had not bade adieu, As if disjoined by soft-handed slumber, And ready still past kisses to outnumber At tender eye-dawn of aurorean love. Це свідчить про те, що для поетики Кітса $є$ типовим використання фріксованих, традиційних епітетів, які зазнають розширення смислу у конкретних поетичних контекстах та відображають специфічні та типові образні моделі.

Образні моделі епітетизачї̈ в поетичнолу дискурсі Дюжона Kimca. У світлі української та зарубіжної когнітивної лінгвістики та 
когнітивної поетики продуктивним є розглядати образні процеси тексту у ракурсі теорії ментальних просторів, згідно з якою ментальні простори структуровано тими сутностями, котрі належать до різних царин словесного поетичного образу і співвідносяться між собою за допомогою мапування [6; 7]. Дослідження епітета можливе з позицій теорії концептуальних просторів, подібно до аналізу метафоричних структур. У результаті застосування теорії концептуальної інтеграції до дослідження семантики епітетів у поезії Джона Кітса на основі семантичного та концептуального аналізів були встановлені типові образні моделі: Образні моделі частотних епітетів у поезї Джона Кітса - Концептосфбера "Людина" ma Концептосфбера "Природа". До прикладу, покажемо специфріку актуалізації образних моделей трьох найбільш частотних епітетів у поезії Джона Кітса - Концептосфрера «Людина»:

Художній мікроконцепт - еуе. Основна образного означення: light, glow, brightness, calmness, behavioral aspect, sensations, feelings, attitude. Типи образної моделі: Людина - людина (фізичне, емоційне, поведінкове, соціальне); Людина - тварина; Людина - фрізичний світ (параметри: світло, колір, температура).

Художній мікроконцепт - hand. Основна образного означення: sensations, feelings, attitude, actions, purity, age, strength, colour. Типи образної моделі: Людина - людина (фpiзичне, емоційне, поведінкове, соціальне); Людина - фозичний світ (параметри: температура, структура).

Художній мікроконцепт - voice. Основна образного означення: music, musical instrument, attitude, sensations, power. Типи образної моделі: Людина - мистецтво (музика); Людина - людин. (емоційне, поведінкове, соціальне); Людина фрізичний світ (параметри: речовина).

Специфріка епітетизації концептосфери «Природа»:

Художній мікроконцепт - day, night, hour. Основна образного означення: age, time, feelings. Типи образної моделі: Час - Людина.

Художній мікроконцепт - heaven, sun, moon, star. Основна образного означення: brightness, colour, actions. Типи образної моделі: Природа - Людина; Природа - природа/фрізичний світ (колір, температура, речовина, якість).

Художній мікроконцепт - flower, cloud. Основна образного означення: colour, purity, sensations, actions. Типи образної моделі: Рослина - Людина; Природа - природа (тварина, речовина).

На основі прикметників - похідних від аналізованих іменників утворено низку метафоричних епітетів та епітетів-персоніфікацій, а також епітетів, які входять до складу метонімій та метафртонімій:

those little bright-eyed things; large-eyed wonder; Whereat, methought, the lidless-eyed train Of planets all were in the blue again; the blear-eyed nations in empurpled vests; The carved angels, ever eager-eyed; Zephyr, blue-eyed Faery; soft-handed slumber; warm-hearted Shakspeare; Sick-hearted, weary - so I took a whim To stray away into these forests drear; hard-hearted times When I had heard e'en of thy death perhaps; A rough-voiced war against the dooming stars; Thy lute-voiced brother will I sing ere long; Free-voiced as one who never was; And in her bearing was a sort of hope; Then old songs waken from enclouded tombs; Spring's honied cud of youthful thought he loves To ruminate, and by such dreaming high Is nearest unto heaven: As thus she quick-voiced spake, yet full of awe.; $O$ let me then by some sweet dreaming flee To her entrancements; And link'd to a dreaming fancy; To show this Castle, in fair dreaming wise; At tender eye-dawn of aurorean love: The winged boy I knew; the sun's bright eye.

На основі частотного аналізу було встановлено співвідношення семантичних типів епітетів: метафоричних та композиційних епітетів та співвідношення фріксованих, конвенційних епітетів та оригінальних, індивідуально-авторських. У результаті було виявлено, що поетичний дискурс Кітса характеризуеться високою частотою використання фіксованих епітетів, які зазнають розширення їхньої семантичної структури та композиційної моделі під впливом контексту. Іменники, які отримують художне означення належать до різноманітних концептуальних доменів - природа, людина, абстрактні поняття, артефракти, мистецтво, світлові та кольорові ознаки об’єктів, фрізичні явища, емоції, стани тощо. Наприклад, здійснений лексикосемантичний та стилістичний аналіз віршів Imitation of Spenser та Ode on a Grecian Urn засвідчує значне переважання фіксованих епітетів над метафоричними епітетами у співвідношення 19:3 та 16:2 відповідно. Для верифрікації наведеного твердження було проведено підрахунки частоти співвідношення фіксованих та оригінальних епітетів на основі 100 ліричних поезій автора. Графрічно визначене співвідношення зображене на рис. 2.

Концептуальна функція епітету в поетичному дискурсі Джона Кітса (на основі частотності прикметників). Прикметник є основним структурним та смислотвірним елементом епітетних структур, оскільки виступає в ролі поетичного, образного означення. Таким чином, на основі частотного аналізу встановлюємо спектр семантичних класів прикметників, які утворюють епітети у поезї Джона Кітса. За даними програми Tropes епітети в аналізованих поетичних текстах належать до семантичних класів: об'єктивних, суб'єктивних та кількісних означень. Лексико-семантичний, стилістичний та контекстуальний аналіз вибраних поетичних контекстів, що містять епітети, однак, дозволяе припустити, що у фонкції епітетів виступають прикметники, що належать до усіх виділених семантичних класів. Поетичні контексти засвідчують однаково частотне використання прикметників (ethereal, silver, numerous, many), що виражають об’ективну та суб’єктивну ознаку у функції художнього атрибута:

Sweet Hope, ethereal balm upon me shed. And wave thy silver pinions o'er my head; The breezes were ethereal, and pure; But let a portion of ethereal dew Fall on my head, That spreading in this dull and clodded earth; Gives it a touch ethereal - a new birth: Be still a symbol of immensity; A firmament reflected in a sea There they discoursed upon the fragile bar That keeps us 


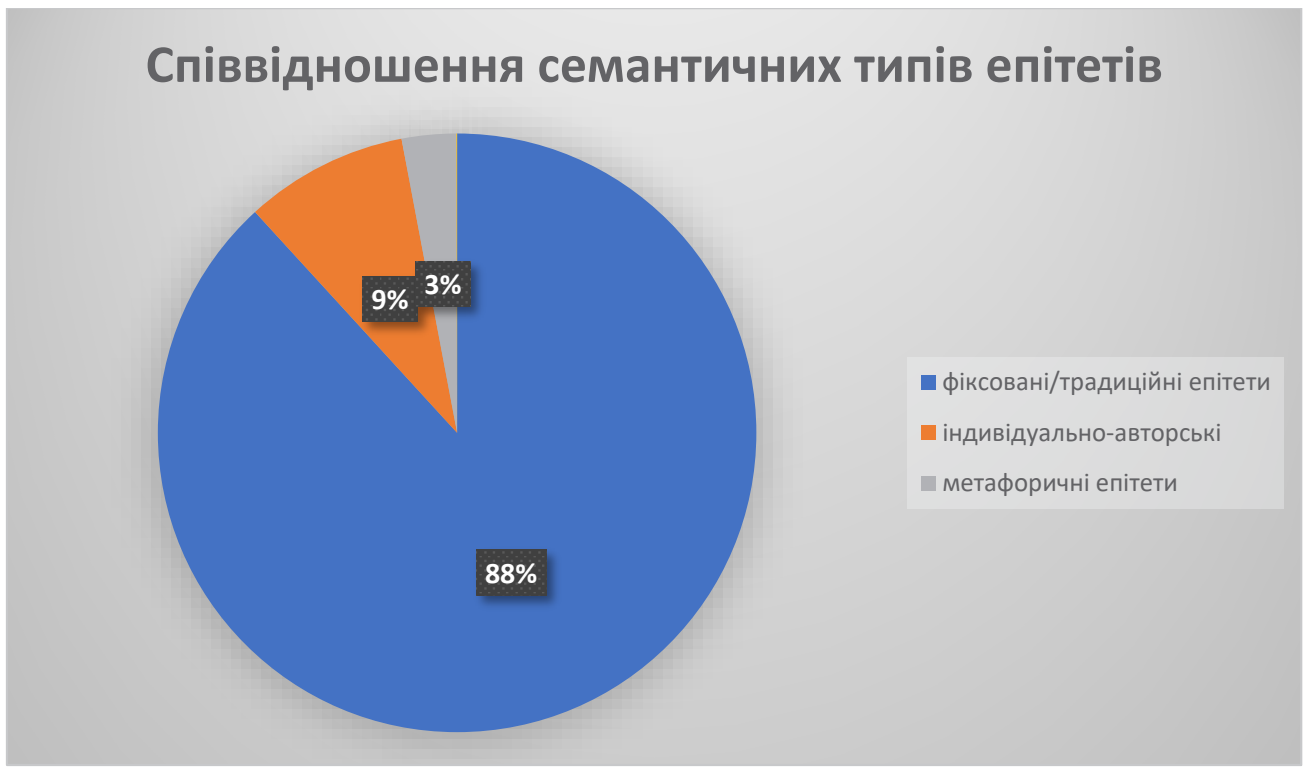

Рис. 2. Частотне співвідношення семантичних типів епітетів у поезії Джона Кітса Джерело: розроблено авторали

from our homes ethereal; And what our duties there: ethereal things that, unconfined; Can make a ladder of the eternal wind, Beyond a mortal man impassion'd far; At these voluptuous accents, he arose, Ethereal, flush'd, and like a throbbing star Seen mid the sapphire heaven's deep repose; And gave a roar, as if of earthly fire, That scared away the meek ethereal Hours And made their dove-wings tremble; And canst oppose to each malignant hour Ethereal presence; And the moon, all silver-proud, Might as well be in a cloud; If a cherub, on pinions of silver descending; ...those silver lamps that burn on high, Or of the distance from home's pleasant lair.

Наступним етапом дослідження було встановлення частотності прикметників у поезії Джона Кітса та визначення основних концептуальних доменів на основі їх частотності. Загальна кількість прикметників - 14283 лексичні одиниці. Було встановлено співвідношення між частотою вживання та частотою епітетизації прикметника у контексті. Частотність та ступінь епітетизації встановили за результатами застосування конкордансу. Найчастотнішим прикметником 3 найвищим ступенем епітетизації є прикметник sweet. Співвідношення частотності вживання та ступеня епітетизації десяти найчастотніших прикметників представлено у таблиці 2 .

Результати свідчать про те, що прикметники 3 високою частотністю переважно мають високий ступінь епітетизації, за незначними винятками. Подібні підрахунки було здійснено для прикметників із середньою та низькою частотністю. Прикметники silver, white, green, deep, clear, silent, cold, wild, незважаючи на їхню середню частотність, мають високий ступінь епітетизації - переважно понад 80\%: All is cold Beauty; pain is never don; those enchantments cold; The grass, the thicket, and the fruit-tree wild; wild commotions; the gentle moon, and freshening beads; The silentblessing fate, warm cloister'd hours; With music wing'd instead of silent plumes; silent happiness.

Поетична мова - це мова художнього мислення та світобачення автора, мова з особливою організацією лексичного складу, емоційно-образна, естетично маркована. Завдяки своїй структурі та семантичному змісту, вона допомагає авторові досягти необхідної образності й емоційної вираз-

Співвідношення частотності вживання та ступеня епітетизації

Таблиця 3 десяти найчастотніших прикметників

\begin{tabular}{|c|c|c|c|}
\hline Прикметник & Чатотність вживання & Частотність епітетів & Ступінь епітетизації \\
\hline sweet & 185 & 176 & $95 \%$ \\
\hline old & 178 & 5 & $2.5 \%$ \\
\hline fair & 162 & 98 & $60.4 \%$ \\
\hline great & 151 & 34 & $22.5 \%$ \\
\hline soft & 135 & 128 & $94.8 \%$ \\
\hline bright & 135 & 122 & $90.4 \%$ \\
\hline gentle & 91 & 76 & $83.5 \%$ \\
\hline golden & 91 & 73 & $50.2 \%$ \\
\hline happy & 85 & 43 & $37.9 \%$ \\
\hline sad & 79 & 30 & \\
\hline
\end{tabular}


ності у змалюванні поетичних картин. Більшість аналізованих прикметників виступають у фрункції постійного фріксованого епітета, який слугує загальною і водночас індивідуальною характеристикою означуваних об'єктів. Підрахунки засвідчили, що домінантними концептуальними доменами, які художньо означуються за допомогою прикметників у поезії Кітса є:

Cобера сенсорних відчутmів - епітети на основі синестезіi: how sweetly sad thy melody, as sweet a silence, sweet sounds, the sweetness Of thy honied voice, sweet dewy blossom, the soft lute, soft music.

Собера елоиійного сприйняття та елоиійного стану суб'єкта: the sweet converse of an innocent mind, sweet privacy, Sweet Hope, sweet head, as sweet a silence, sweet rest, a sweet reprieve, faintness solemn, sweet, and slow, thy sweetest comforts, sweet enforcement and remembrance dear, fair dreams, fair sooth, your brightest looks, soft ease, soft-handed slumber, the soft luxury, gentle amity, a gentle luxury, The gentle heart, love's most gentle stream, her gentle soul.

Абстрактні поняття, сбера релігійного, міgbічного: sweet poets, fair nymphs, heaven fair.

Сбера суб'єктивної оиінки об'єкта поетичного зображення (колір, час, температура, світло, фрізичні параметри тощо): thy fair morning, fair dawn Of life, fair blossom'd boughs, fair day, her fair cheek more fair, those fair stars, fair trees, the bright mists, the bright waters, a bright casket of pure gold, soft shade, Soft breezes, gentle windings.

Засобами створення емоційної атмосфери в поетичному контексті е метафоричні епітети. Вони є словесними прикрасами, які збагачують мову, вносячи в неї певну семантичну новизну. Кількісний аналіз свідчить про те, що найбільшою $є$ група сенсорних епітетів, що становить приблизно 67\% від загальної кількості метафоричних епітетів. Серед зображуваних об'єктів метафоричними епітетами автор здебільшого характеризуе різноманітні аспекти сприйняття довкілля людиною - ліричним героєм, поетом. Спостерігаємо також незначну частотність епітетів-оксиморонів: Her wild and timid nature, All is cold Beauty; those enchantments cold; Smiling and cold and gay pleasing woe.

Висновки і пропозиції. У роботі на основі частотного аналізу із застосуванням програми семантичного аналізу текстів Tropes та програми-конкордансу Ant.conc. було визначено когнітивну та концептуальну фрункцію епітета у поезії Джона Кітса. Основою визначення авторської концептосистеми стало застосування кількісного аналізу лексичного наповнення поетичних контекстів Джона Кітса. За допомогою програми було встановлено контексти мікроконцептів, що зазнають найвищої епітетизації. Найчастотнішими образними моделями, на основі яких створені поетичні епітети є: Людина - людина (фізичне, емоційне, поведінкове, соціальне); Людина - тварина; Людина - фізичний світ (параметри: світло, колір, температура); Людина мистецтво (музика); Людина - людина (емощійне, поведінкове, соціальне); Людина - фрізичний світ (параметри: речовина).

На основі прикметників утворено низку метафоричних епітетів та епітетів-персоніфікацій, а також епітетів, які входять до складу метонімій. Іменники, які отримують художне означення, належать до різноманітних концептуальних доменів - природа, людина, абстрактні поняття, артедакти, мистецтво, світлові та кольорові ознаки об'єктів, фрізичні явища, емощії, стани тощо. Було встановлено співвідношення між частотою вживання та частотою епітетизації прикметника у контексті. Результати свідчать про те, що прикметники з високою частотністю переважно мають високий ступінь епітетизації.

Отже, епітет займає суттеве місце у поетиці Джона Кітса. Поет асимілюе традищійні образні форми, сталі, фріксовані епітети, наповнюючи їх новими смислами в межах конкретних поетичних контекстів. Відповідно, частка асоційованих епітетів $є$ вищою порівняно з унікально-авторськими епітетами. Стилетвірною функцією наділені епітети, створені на основі художнього переносу прикметників sweet, soft, bright, які характеризуються найвищою частотністю та відображають ідостилістичні предеренції до створення образів на основі принципу синестезії, переважання чуттево-емоційного компонента у художньому сприйнятті дійсності.

Звернення лінгвістики тексту до кількісних методів та корпусних технологій пов'язана, окрім прагнення до вищого рівня формалізащії мовних даних, до всеохопного аналізу та зіставлення великого об'єму мовних даних, яке допомагає дослідникам прийти до нових висновків про динаміку авторського стилю. Однак, статистичні параметри не є самоціллю аналізу художнього тексту. Адже худложне слово за своєю природою багатопланове. Його дослідження вимагає інтеграції різних дослідницьких підходів та вибору об'єкта аналізу

Проведене дослідження може стати основою для укладання авторського словника епітетів та інших образних ресурсів, що сприятиме розвиткові не лише лінгво- та когнітивної поетики, а й ідеографрічної лексикографії.

\section{Список літератури:}

1. Москвин В. Русская метафора. Очерк семиотической теории. Москва : ЛЕНАНД, 2006. 184 с.

2. Онопрієнко T.M. Тропеїчні засоби реалізації прагматичної скерованості художнього тексту. URL: http://eprints.zu.edu.ua (дата звернення: 26.11.2021).

3. Романишин Н. Національна ідентичність в поезії англійського романтизму. Львів : Видавництво Львівської політехніки, 2021. 536 с.

4. Словник епітетів української мови / заг. ред. С.П. Бибик, С.С. Срмоленко, Л.О. Пустовіт. Київ, 1998.431 с.

5. Томашевский Б. Стилистика. Ленинград : Издательство Ленинградского университета, 1983. 204 с.

6. Evans, V. Cognitive Linguistics. Edinburgh : Edinburgh University Press, 2006. 672 p.

7. Fauconnier, G., Turner, M. The way we think: Conceptual blending and the mind's hidden complexities. 2002.440 p. 


\section{References:}

1. Bybyck S.P. (ed.) (1998) Slovnyk epitetiv ukrayinskoyi movy [Dictionary of epithets in the Ukrainian language]. Kyiv. (in Ukrainian)

2. Moskvin V. (2006) Russkaya metafora. Ocherk semioticheskoj teorii [Russian metaphor. An Essay on the semiotic theory of metaphor]. Moscow: LENAND. (in Russian)

3. Onopriyenko T.M. Tropeyichni zasoby realizaciyi pragmatychnoyi skerovanosti xudozhnogo tekstu [Tropeic means of realization of the pragmatic direction of the literary text]. Available at: http://eprints.zu.edu.ua (accessed 26 November 2021). (in Ukrainian)

4. Romanyshyn N. (2021) Nacionalna identychnist $v$ poeziyi anglijskogo romantyzmu [National identity in the poetry of English Romanticism]. Lviv: Vydavnycztvo Lvivskoyi politexniky. (in Ukrainian)

5. Tomashevskiy B. (1983) Stilistika [Stylistics]. Lieningrad: Izdatelstvo Lieningradskogo universitieta. (in Russian)

6. Evans V. (2006) Cognitive Linguistics. Edinburgh: Edinburgh University Press.

7. Fauconnier G., Turner M. (2002) The way we think: Conceptual blending and the mind's hidden complexities. 